\title{
Retraction Note: A note on the unsteady flow of a fractional Maxwell fluid through a circular cylinder
}

\author{
M. Athar · A. U. Awan · Corina Fetecau
}

(C)The Chinese Society of Theoretical and Applied Mechanics and Springer-Verlag Berlin Heidelberg 2012

Retraction to: Acta Mechanica Sinica (2012) 28(2): 308-314 DOI 10.1007/S10409-012-0004-Z

This article is retracted at the request of the Editorin-Chief because of similarity to previously published ma- terial, specifically that in the first paragraph of article: Exact solutions for the Poiseuille flow of a generalized Maxwell fluid induced by time-dependent shear stress published on Anziam J. 51, 416-429 (2010) with DOI: $10.1017 /$ S1446181111000514.

The online version of the original article can be found under doi 10.1007/S10409-012-0004-Z.

\footnotetext{
M. Athar (殴 · A. U. Awan · Corina Fetecau Abdus Salam School of Mathematical Sciences, GC University Lahore, 68-B, New Muslim Town Lahore, Pakistan e-mail: athar_sms@yahoo.com 